Volume 15, No. 2, Juli 2018

\title{
FAKTOR FISIK DAN BIOLOGI DENGAN KELUHAN SUBYEKTIF SICK BUILDING SYNDROME
}

\author{
Endah Aryadni, Juanda, Imam Santoso \\ Poltekkes Kemenkes Banjarmasin Jurusan Kesehatan Lingkungan \\ Jl. H. Mistar Cokrokusumo No. 1A Banjarbaru Kalimantan Selatan 70714 \\ Email : aryadniendah@gmail.com
}

\begin{abstract}
Physical And Biology Factor with Sick Building Syndrome Subjective Complaint. One of disturbance health phenomenalism that linked to air quality is Sick Building Syndrome (SBS). SBS is symptom collections whom felt by employeer in a work room that linked to duration of work and air quality. This research used explanatory research by cross sectional approachment. Total population used to sample collection that count of 44 respondents. Research variable for unimpeded variables were temperature, humidity, illumination, amount of air bacteria, age, work duration per day and year of work whereas impeded variable was Sick Building Syndrome subjective complaint. Technical of data collection were measuring, observation and quiz. Data analyze method used univariat analyze with descriptive, and bivariat analyze with spearman's rho correlation. Outcome of research showed that there were no relation between temperature with $p$ value 0,716 > 0,05 , humidity with $p$ value $0,818>0,05$, illumination with $p$ value $0,529>0,05$ and amount of air bacteria with $p$ value $0,759>0,05$ to SBS subjective complaint in office work room of RRI Banjarmasin.
\end{abstract}

Keywords: Physical Factor; Biology; Sick Building Syndrome

\begin{abstract}
Abstrak: Faktor Fisik Dan Biologi dengan Keluhan Subyektif Sick Building Syndrome. Salah satu fenomena gangguan kesehatan yang berhubungan dengan kualitas udara dalam ruang adalah Sick Building Syndrome (SBS). SBS adalah kumpulan gejala yang dialami oleh pegawai dalam gedung perkantoran berhubungan dengan lamanya berada di dalam gedung serta kualitas udara. Penelitian ini menggunakan desain explanatory research dengan pendekatan cross sectional. Teknik pengambilan sampel menggunakan total population yang berjumlah 44 responden. Variabel penelitian terdiri dari variabel bebas yaitu suhu, kelembaban, pencahayaan, angka kuman, umur, lama kerja dalam 1 hari dan masa kerja sedangkan variabel terikat adalah keluhan subyektif SBS. Teknik pengumpulan data dengan metode pengukuran, observasi dan kuesioner. Metode analisis data menggunakan analisis univariat dengan analisis deskriptif dan uji bivariat dengan korelasi spearman's rho. Hasil penelitian menunjukkan bahwa tidak ada hubungan antara suhu dengan hasil $p$ value $0,716>0,05$, kelembaban dengan $p$ value $0,818>0,05$, pencahayaan dengan $p$ value $0,529>0,05$ dan angka kuman udara dengan $p$ value 0,759 > 0,05 dengan keluhan subyektif SBS pada ruangan kantor RRI Banjarmasin.
\end{abstract}

Kata kunci: Faktor Fisik; Biologi; Sick Building Syndrome

\section{PENDAHULUAN}

Dua puluh tahun belakangan ini di dunia banyak sekali dibangun gedung bertingkat tertutup rapat lengkap dengan ventilasi udara yang tergantung sepenuhnya pada mesin, seperti kantor yang merupakan salah satu tempat kerja yang menggunakan ventilasi dengan sistem Air Conditioner (AC). Hal tersebut menyebabkan polusi, terutama polusi udara yang diakibatkan ventilasi sistem Air Conditioner mempunyai sirkulasi udara 
sendiri, sehingga akan mempengaruhi kualitas udara dalam ruangan[1].

Salah satu fenomena gangguan kesehatan yang berkaitan dengan kualitas udara di dalam ruangan adalah Sick Building Syndrome (SBS). Sick Building Syndrome adalah keadaan yang menyatakan bahwa gedung industri, perkantoran, perdagangan, dan rumah tinggal memberikan dampak penyakit dan merupakan kumpulan gejala yang dialami oleh pekerja dalam gedung perkantoran berhubungan dengan lamanya berada di dalam ruangan serta kualitas udara[2].

Radio Republik Indonesia Banjarmasin merupakan salah satu bangunan bertingkat yang didalamnya berlangsung berbagai aktivitas, terutama oleh pegawai. RRI Banjarmasin dibangun pada tahun 1979 dan diresmikan pada tahun 1982. Bangunan ini menggunakan jendela tertutup dan ventilasi buatan menggunakan AC. Hal ini dapat mempengaruhi kualitas udara dalam ruangan dan berisiko menimbulkan gejala SBS pada pegawai di dalamnya yang terpapar selama bekerja.

\section{BAHAN DAN CARA PENELITIAN}

Populasi dalam penelitian ini adalah seluruh pegawai RRI Banjarmasin berjumlah 44 pegawai dengan kriteria inklusi yaitu pegawai yang bekerja di dalam ruangan kantor RRI Banjarmasin, memiliki jam kerja 8 jam per hari, bersedia dijadikan responden penelitian.

Sampel penelitian adalah seluruh pegawai RRI Banjarmasin berjumlah 44 pegawai. Titik pengambilan sampel yang meliputi suhu, kelembaban, pencahayaan dan angka kuman udara dalam ruangan dilakukan pada 11 ruangan yaitu ruang kepala RRI, bidang pemberitaan, teknik, sekretariat, editing, multimedia, pustaka musik, MCR, programma 1, programma 2 dan programma 4.
Desain atau rancang bangun penelitian menggunakan pendekatan melintang (cross sectional) untunk mengetahui hubungan faktor fisik (suhu, kelembaban, pencahayaan), faktor biologi (angka kuman udara) dengan keluhan subyektif SBS pada pegawai RRI Banjarmasin tahun 2017 berupa analisis univariat dan bivariat. Analisis univariat mendeskripsikan karakteristik responden yang diteliti meliputi umur, lama kerja dalam 1 hari dan masa kerja, hasil pengukuran faktor fisik meliputi suhu, kelembaban dan pencahayaan, faktor biologi meliputi angka kuman udara serta keluhan subyektif SBS. Analisis bivariat menggunakan uji spearman rho dengan Confidence Level (CL) sebesar $95 \%$ atau tingkat kemaknaan $\alpha=0,05$ untuk mengalisis hubungan faktor fisik dan biologi dengan keluhan subyetif SBS pada pegawai RRI Banjarmasin tahun 2017.

\section{HASIL DAN PEMBAHASAN}

Karakteristik responden terdiri dari berumur 21-30 tahun sebanyak 1 orang (2,3\%) dan yang berumur 51-60 sebanyak 25 orang $(56,8 \%)$ dengan lama kerja dalam 1 hari responden adalah 8 jam yaitu sebanyak 44 orang (100\%). Masa kerja responden $<5$ tahun adalah sebanyak 2 orang $(4,5 \%)$.

Pengukuran suhu, kelembaban, pencahayaan dan angka kuman dilakukan pada ruangan sekretariat, pemberitaan, teknik, programma 2, programma 4. Editing, MCR, pustaka music, programma 1, multimedia dan ruang Kepala RRI. Hasil pengukuran menunjukkan suhu yang tidak memenuhi standar terdapat pada ruangan teknik dan ruangan MCR yaitu $29^{\circ} \mathrm{C}$. Pengukuran kelembaban juga dilakukan pada ruangan yang sama, kelembaban ruangan yang tidak memenuhi standar terdapat pada ruangan pemberitaan $62 \%$ dan ruangan teknik $63 \%$. 
Hasil pengukuran pencahayaan diketahui bahwa pencahayaan dalam ruang yang memenuhi standar hanya pada ruang sekretariat yaitu 226 lux, ruang pemberitaan 123 lux, ruang editing 101 lux dan ruang programma 1.130 lux. Hasil pengukuran faktor biologi yaitu angka kuman diketahui bahwa jumlah angka kuman yang memenuhi standar hanya terdapat pada ruangan teknik 240 $\mathrm{CFU} / \mathrm{m}^{3}$, ruang pustaka musik 501 $\mathrm{CFU} / \mathrm{m}^{3}$ dan ruang programma 1640 $\mathrm{CFU} / \mathrm{m}^{3}$.

Keluhan Subyektif Sick Building Syndrome dapat diketahui bahwa jumlah responden yang merasakan keluhan subyektif SBS sebanyak 14 responden $(31,8 \%)$.

Hubungan suhu dengan keluhan subyektif SBS dapat diketahui bahwa yang paling banyak merasakan keluhan subyektif SBS yaitu dengan suhu yang memenuhi standar sebanyak 11 pegawai (33,3\%).

Hubungan Kelembaban dengan Keluhan Subyektif Sick Building Syndrome dapat diketahui bahwa yang paling banyak merasakan keluhan subyektif SBS yaitu dengan kelembaban yang memenuhi standar sebanyak 8 pegawai $(33,3 \%)$.

Hubungan Pencahayaan dengan Keluhan Subyektif Sick Building Syndrome dapat diketahui bahwa yang paling banyak merasakan keluhan subyektif SBS yaitu dengan pencahayaan yang tidak memenuhi standar sebanyak 8 pegawai (36,4\%).

Hubungan Angka Kuman Udara dengan Keluhan Subyektif Sick Building Syndrome dapat diketahui bahwa yang paling banyak merasakan keluhan subyektif sick building syndrome (SBS) yaitu dengan angka kuman udara dalam ruangan yang tidak memenuhi standar sebanyak 10 pegawai $(33,3 \%)$ dengan $p$ value 0,759 .
Pegawai RRI Banjarmasin hampir keseluruhan menikmati adanya penggunaan AC dalam ruangan saat bekerja karena hal ini menjadi kebutuhan pokok bagi sebuah lingkungan kerja yang menjadi alternatif utama kenyamanan dalam bekerja. Uji statistik menggunakan korelasi Spearman's rho menunjukkan $p$ $0,716>0,05$ sehingga disimpulkan bahwa suhu tidak berhubungan dengan keluhan subyektif SBS. Hal ini sejalan dengan penelitian Ahmad (2011) dan Ardian \& Sudarmaji (2014) bahwa suhu lingkungan kerja tidak berpengaruh signifikan terhadap munculnya gejala SBS. Hal ini dapat terjadi karena suhu lingkungan kerja masih pada batas normal untuk lingkungan kerja, dan dengan suhu normal tersebut menyebabkan tubuh pekerja tidak mengeluarkan energi yang banyak untuk beradaptasi dengan lingkungan sekitar.

Berdasarkan uji statistik menggunakan korelasi Spearman's rho menunjukkan bahwa $p 0.818>0,05$ yang berarti tidak ada hubungan antara kelembaban dengan keluhan subyektif SBS. Hal ini sejalan dengan penelitian yang dilakukan oleh Laila (2011) dan Ardian (2014) yang menemukan bahwa tidak ada pengaruh yang signifikan antara kelembaban terhadap keluhan SBS. Berdasarkan pengukuran kelembaban diketahui bahwa terdapat 9 dari 11 ruangan memenuhi standar menurut Kepmenkes RI Nomor 1405/MENKES/SK/ $\mathrm{XI} / 2002$ tentang Persyaratan dan Tata Cara Penyelenggaraan Kesehatan Lingkungan Kerja yaitu 40-60 \%, ruangan yang tidak memenuhi standar yaitu ruang pemberitaan $62 \%$ dan ruang teknik $63 \%$. Hasil uji statistik menunjukkan bahwa $p 0,529>0,05$ yang berarti tidak ada hubungan pencahayaan dengan keluhan subyektif SBS. Penelitian ini sejalan dengan penelitian Laila (2011) 
bahwa pencahayaan ruangan di tempat kerja bukan merupakan pemicu keluhan SBS. Hal ini dapat terjadi mungkin karena berkaitan dengan lama kerja responden yang terlalu lama kemungkinan pekerja sudah terbiasa dengan kondisi pencahayaan yang ada sehingga tetap dapat bekerja dengan baik.

Hasil uji statistik menunjukkan bahwa $p \quad 0,759>0,05$ yang berarti tidak ada hubungan angka kuman udara dengan keluhan subyektif SBS. Pada pemeriksaan angka kuman udara di 11 ruangan, hanya terdapat 3 ruangan yang memenuhi standar yaitu ruang teknik $\left(240 \mathrm{CFU} / \mathrm{m}^{3}\right)$, pustaka musik $\left(501 \mathrm{CFU} / \mathrm{m}^{3}\right)$ dan programma $1\left(640 \mathrm{CFU} / \mathrm{m}^{3}\right)$. Banyaknya ruangan yang tidak memenuhi standar pada parameter angka kuman kemungkinan disebabkan karena seringnya pintu ruangan dibuka dan ditutup yang dapat menyebabkan polutan dari luar ruangan masuk, penggunaan karpet dan tidak dilakukannya desinfeksi sehingga berpotensi untuk menyebabkan penyakit.

SBS merupakan kumpulan gejala yang disebabkan oleh buruknya kualitas udara dalam ruangan yang terjadi minimal satu gejala dirasakan oleh $30 \%$ dari total responden di dalam gedung (WHO,2005). Dalam penelitian ini, responden yang mengalami gejala SBS sebanyak 14 responden (31,8\%) dan yang tidak mengalami gejala SBS sebanyak 30 responden (68,2\%). Maka dapat disimpulkan bahwa kantor RRI Banjarmasin tergolong gedung perkantoran yang memenuhi kriteria Sick Building Syndrome (SBS).

\section{KESIMPULAN DAN SARAN}

Berdasarkan hasil penelitian dan pembahasan dapat disimpulkan tidak ada hubungan antara suhu udara dengan keluhan subyektif sick building syndrome pada pegawai RRI Banjarmasin, tidak ada hubungan antara kelembaban udara dengan keluhan subyektif sick building syndrome pada pegawai RRI Banjarmasin, tidak ada hubungan antara pencahayaan dengan keluhan subyektif sick building syndrome pada pegawai RRI Banjarmasin dan tidak ada hubungan antara angka kuman udara dengan keluhan subyektif sick building syndrome pada pegawai RRI Banjarmasin.

Saran yang dapat diberikan dalam penelitian ini adalah bagi Pengelola RRI Banjarmasin untuk menjaga suhu, kelembaban, penataan pencahayaan dan pemeliharaan rutin Air Conditioner (AC) dalam ruangan agar tetap dalam keadaan sesuai standar yang ditetapkan. Bagi Pegawai RRI Banjarmasin dalam bekerja sebaiknya pegawai meluangkan waktu sejenak untuk melakukan peregangan otot dan penyegaran supaya fokus dapat dikembalikan maksimal dan minat dalam bekerja supaya terhindar dari kejenuhan yang memicu pada gejala SBS serta tidak merokok didalam ruangan ber-AC. Bagi Peneliti selanjutnya perlu dilakukan penelitian lanjutnya dengan variabel lainnya yang tidak diteliti pada penelitian ini seperti kecepatan udara dan debu total dalam ruangan terhadap keluhan SBS untuk mengetahui apakah ada hubungan antara variabel tersebut dengan gejala SBS pada pegawai.

\section{KEPUSTAKAAN}

1. Aditama, T. Y. \& Hastuti, T. (2002). Kesehatan Dan Keselamatan Kerja. Jakarta: Penerbit Universitas Indonesia

2. Dian Yulianti, Mukhtar Ikhsan, Wiwien Heru Wiyono, (2012). "Sick Building Syndrome" Departemen Pulmonologi dan Ilmu Kedokteran Respirasi, Fakultas Kedokteran Universitas Indonesia-RS Persahabatan, Jakarta, CDK-189/ vol. 39 no. 1

3. Hasil Pemeriksaan Laboratorium Kesehatan Provinsi Kalimantan Selatan 
4. Keputusan Menteri Kesehatan RI No. 1405/Menkes/SK/XI/2002 tentang Kesehatan Lingkungan Kerja Perkantoran dan Industri

5. Laila, Nur Najmi (2011). Faktor-Faktor Yang Berhubungan Dengan Keluhan Sick Building Syndrome (SBS) Pada Pegawai di Gedung Rektorat Syarif Hidayatullah Jakarta Tahun 2011. Skripsi. Universitas Islam Negeri Syarif Hidayatullah. Jakarta.

6. Notoatmodjo, S. (2012). Metodologi Penelitian Kesehatan. Jakarta: Rineka Cipta.
7. Profil RRI Banjarmasin Tahun 2017

8. Sujarweni, V. W. (2014). Metodologi Penelitian. Yogyakarta: Pustaka Baru Press.

9. Sastroasmoro, Sudigdo, dan Sofyan Ismail. (2010). Dasar - dasar Metode Penelitian Klinis . In: Pemilihan Subyek Penelitian dan Desain Penelitian. Jakarta: Sagung Seto

10. US EPA. (1991). Indoor Air Facts No. 4 (Revised). Sick Building Syndrome, Researchand Development : (8105) 402-F-94-004 April 1991 
